\title{
Hubungan Kemampuan Guru Bimbingan dan Konseling Membina Hubungan Konseling dengan Motivasi Siswa Melanjutkan Konseling
}

Siti Khomsiyati

Universitas Negeri Padang

\section{Abstract}

Penelitian ini berawal dari rendahnya kinerja dosen penasehat akademik yang diketahui berdasarkan wawancara yang dilakukan dengan mahasiswa jurusan TV dan FILM ISI Padangpanjang. Kinerja dosen penasehat akademik adalah sesuatu yang telah dicapai oleh dosen penasehat akademik yang diukur melalui persepsi mahasiswa dalam melaksanakan tugas dan tanggung jawab yang diberikan kepadanya berdasarkan kompetensi yang dimilikinya. Jenis penelitian adalah korelasional deskriptif. Dalam penelitian ini terdapat populasi sebesar 135, teknik pengambilan sampel teknik Simple Random Sampling dan diperoleh jumlah sampel 100. Pengumpulan data dengan skala likert, dan analisis data dengan analisis deskriptif korelasional. Hasil penelitian menunjukkan bahwa kinerja dosen PA berkategori rendah dan masalah akademik mahasiswa berada pada kategori sedang, , sehingga dapat disimpulkan bahwa hubungan antara kinerja dosen PA dengan masalah akademik mahasiswa. Tingkat korelasi antara kinerja dosen PA dengan masalah akademik mahasiswa sangat rendah atau tidak terlalu signifikan bahkan bisa dikatakan hampir tidakberkorelasi sama sekali.

Keyword: helping relationships, motivation counseling.

Copyright @ 2013 IICE - Multikarya Kons (Padang - Indonesia) dan IKI - Ikatan Konselor Indonesia - All Rights Reserved

Indonesian Institute for Counseling and Education (IICE) Multikarya Kons

\section{PENDAHULUAN}

Konseling merupakan pelayanan yang memfasilitasi siswa untuk dapat menjadi pribadi yang lebih baik. Perkembangan yang terjadi dewasa ini pada sekolah-sekolah menengah pertama menunjukkan bahwa pelaksanaan layanan bimbingan konseling terutama konseling perorangan belum terlaksana dengan baik. Menurut Yusuf dan Nurihsan (2008:37) kebanyakan siswa yang memiliki permasalahan di sekolah enggan datang ke ruangan BK bukan karena disebabkan oleh keterbatasan Konselor dalam hal keilmuan Bimbingan dan Konseling, tetapi karena mereka memiliki kesan bahwa guru BK tidak menunjukkan kepedulian, keakrabannya dan perhatian. Lesmana (2005:48) mengemukakan bahwa banyak klien yang merasa enggan untuk meminta bantuan kepada guru BK, meskipun ia merasa memerlukan bantuan. Konselor yang bersikap hangat, penuh keakraban terhadap konseli akan membangun motivasi siswa untuk mengikuti konseling dalam rangka memperoleh harapan-harapan tertentu (Moh. Surya, 1988: 133). Lebih lanjut Moh. Surya mengutip pernyataan Goldstein menjelaskan bahwa sikap guru BK memiliki pengaruh yang lebih besar dalam keberhasilan proses konseling. Sikap dan keterbukaan guru BK akan menjadi 
faktor pendorong bagi siswa untuk mengikuti proses konseling. Motivasi memiliki peranan yang penting dalam diri seseorang untuk melakukan sesuatu. Dalam proses konseling motivasi sangat diperlukan, sebab seseorang yang tidak mempunyai motivasi dalam konseling, akan sulit melakukan proses konseling.

Keberhasilan penyelenggaraan proses konseling sangat dipengaruhi oleh kemampuan konselor atau guru BK dalam membina hubungan yang baik dengan konseli. Membina hubungan dalam proses konseling merupakan suatu kemampuan yang harus dikembangkan oleh konselor. Kemampuan membina hubungan akan berpengaruh terhadap pandangan siswa terhadap konselor, sikap siswa untuk percaya terhadap konselor, dan keterbukaan dalam mengungkapkan masalah yang sedang dialami kepada konselor (Munro, 1983:35).

Pepinskys' (dalam L.M Brammer, 1982:144) mendefinisikan hubungan (relantionship) adalah,”...as hypothetical construct to designate the inferred effective character of the observable interaction between two individuals. Proses membina hubungan sering kali disebut sebagai fase dalam membentuk suatu hipotesishipotesis yang bersifak afektif, baik dari klien ataupun dari konselornya sendiri. Dengan demikian peran konseling dalam membangun kepercayaan klien pada konselor dan proses konseling dibentuk dari hubungan yang dibina oleh konselor itu sendiri.

Berdasarkan hasil wawancara yang dilakukan, diperoleh keterangan bahwa siswa enggan untuk datang ke ruang BK dan mengikuti pelayanan konseling atau melanjutkan konseling yang pernah ia lakukan dengan guru BK. Siswa-siswi tersebut mengungkapkan alasan mereka enggan datang keruang BK karena guru BK dalam melaksanakan proses konseling kurang peduli atau memperhatikan siswa. Siswa menjelaskan bahwa pada saat proses konseling guru BK mengobrol dengan sesama guru yang kebetulan berada di ruang BK, sehingga siswa tersebut merasa tidak diperhatikan. Siswa yang mengikuti konseling kebanyakan bukan karena kemauannya sendiri, tetapi karena dipanggil oleh guru BK. Selain itu, alasan lain adalah sikap guru BK yang kurang ramah atau tidak akrab ketika menyambut klien yang datang, guru BK cenderung memposisikan pihak yang dibutuhkan dalam proses konseling sehingga menjadi paling aktif sedangkan klien hanya sebagai pendengar, guru BK sering sekedar memberikan nasehat setelah itu siswa dipersilahkan keluar ruangan BK.

Menanggapi keterangan yang diberikan oleh siswa tersebut, peneliti tertarik untuk mengungkapkan lebih lanjut meneliti tentang motivasi siswa melanjutkan konseling. Untuk itu, peneliti kembali mengadakan wawancara dengan lima siswa SMP Negeri 13 Padang yang pernah mengikuti konseling pada tanggal 19 November. Berdasarkan wawancara tersebut, rata-rata siswa merasa malas untuk kembali melanjutkan konseling. Menurut siswa tersebut, ketika melakukan proses konseling guru BK cenderung memberikan nasehat sehingga siswa bosan, siswa merasa tidak diperhatikan, siswa merasa kurang akrab dengan guru BK dalam proses konseling, dan siswa masih ragu dengan guru BK bisa mengatasi masalah mereka.

Berdasarkan permasalahan di atas, maka rumusan masalah dalam penelitian ini sebagai berikut: 1) Bagaimanakah kemampuan guru BK dalam membina hubungan konseling ditinjau dari aspek: kepedulian dan kehangatan, empati, dan kesegaraan ?. 2) Bagaimana motivasi siswa untuk melanjutkan konseling? 3) Apakah terdapat hubungan antara kemampuan guru BK dalam membina hubungan konseling dengan motivasi siswa melanjutkan konseling?

Tujuan penelitian ini adalah untuk: 1) Memperoleh gambaran tentang kemampuan guru BK dalam membina hubungan konseling, ditinjau dari aspek: kepedulian dan kehangatan guru BK, empati guru BK, dan kesegeraan guru BK dalam konseling. 2) Mengungkap seberapa besar motivasi siswa untuk melanjutkan konseling. 3) Mengetahui hubungan antara kemampuan guru BK dalam membina hubungan konseling dengan motivasi siswa melanjutkan konseling.

\section{METODOLOGI}

Penelitian ini merupakan penelitian Ex Post Facto. Penelitian Ex Post Facto adalah penyelidikan empiris yang sistematis, dimana peneliti tidak mengendalikan variabel bebas secara langsung karena eksistensi dari variabel tersebut telah terjadi (Emzir, 2008: 119). Pendekatan penelitian yang digunakan adalah deskriptif dan pendekatan korelasional. Menurut A. Muri Yusuf (2005: 84) Penelitian korelasional merupakan tipe penelitian yang meilhat antara satu atau beberapa ubahan dengan satu atau beberapa ubahan yang lain. Penelitian 
korelasional dipilih karena peneliti ingin mengetahui tentang kuat atau lemahnya hubungan variabel yang terkait dalam penelitian, yaitu membina hubungan konseling dan motivasi siswa melanjutkan konseling.

Analisis yang digunakan dalam penelitian ini adalah analisis deskriptif. Analisis deskriptif merupakan usaha untuk mendapatkan informasi yang lebih mendalam dan luas, atau untuk dapat menentukan hubungan beberapa perubahan atau untuk memperjelas dan mempertajam konsep (A. Muri Yusuf, 2005: 83). Dengan melakukan analisis deskriftif, diharapkan penelitian ini dapat mengungkapkan secara mendalam kemampuan konselor membina hubungan konseling, dan motivasi siswa untuk melanjutkan konseling. Sedangkan untuk melihat hubungan antara kemampuan guru BK dalam membina hubungan konseling dengan motivasi siswa melanjutkan konseling, maka dilakukan dengan analisis korelasional.

Karakteristik populasi dalam penelitian ini adalah siswa kelas VII dan VIII SMP N 13 Padang, yang pernah mengikuti pelayanan konseling pada semester 1 tahun pelajaran 2012/2013. Berdasarkan penyebaran daftar pertanyaan yang sesuai dengan karakteristik populasi, maka diperoleh populasi penelitian sebesar 119 siswa yang pernah konseling. Untuk menentukan sampel penelitian, peneliti menggunakan teknik Purposive Sampling yaitu penentuan sampel didasarkan pada maksud yang telah ditetapkan sebelumnya ( A. Muri Yusuf, 2005: 205). Melalui teknik Purposive Sampling, peneliti mengambil sampel penelitian dengan karakteristik pernah mengikuti konseling lebih dari 2 kali, sehingga diperoleh jumlah 66 siswa.

\section{HASIL}

sesuai dengan tujuan penelitian, maka hasil penelitian akan disajikan menjadi beberapa bagian sehingga akan mudah memahami hasil penelitian yang telah diperoleh. Hasil penelitian secara rinci disajikan sebagai berikut.

a. Kemampuan Guru BK Membina Hubungan Konseling.

Tabel 1.

Rangkuman Perhitungan Data Kemampuan Guru BK Membina Hubungan Konseling.

\begin{tabular}{|l|l|}
\hline Mean & 150 \\
\hline Median & 152,50 \\
\hline Mode & 149 \\
\hline Standar deviasi & 16,318 \\
\hline Skor minimal & 83 \\
\hline Skor maksimal & 181 \\
\hline Total skor & 9904 \\
\hline
\end{tabular}

Rangkuman perhitungan data tersebut akan dibandingkan dengan pengkategorian yang telah ditetapkan sebagai berikut.

Tabel 2.

Kategori Pencapaian Skor Kemampuan Guru BK Membina Hubungan Konseling

\begin{tabular}{|c|c|}
\hline Klasifikasi & Kategori \\
\hline 163 & Sangat tinggi \\
\hline $131-162$ & Tinggi \\
\hline $99-130$ & Sedang \\
\hline $66-98$ & Rendah \\
\hline$\leq 65$ & Sangat rendah \\
\hline
\end{tabular}


Dari hasil perhitungan dan setelah dibandingkan dengan kategori yang telah ditetapkan, rata-rata pencapaian skor berada pada kategori tinggi, dengan demikian disimpulkan bahwa kemampuan guru BK membina hubungan konseling di SMP Negeri 13 Padang berada pada kategori tinggi.

Tabel 3.

Rekapitulasi perolehan skorkemampuan guru BK membina hubungan konseling untuk setiap indikator

\begin{tabular}{|c|l|c|c|c|c|c|}
\hline No & $\begin{array}{c}\text { Indikator Kemampuan } \\
\text { membina hubungan konseling }\end{array}$ & SI & ST & SR & Rata-rata & Ket \\
\hline 1 & Kepedulian dan kehangatan & 75 & 70 & 34 & 59,71 & $\mathrm{~T}$ \\
\hline 2 & Empati & 70 & 66 & 33 & 53,06 & $\mathrm{~T}$ \\
\hline 3 & Kesegeraan & 50 & 47 & 16 & 37,29 & $\mathrm{~T}$ \\
\hline
\end{tabular}

b. Motivasi siswa melanjutkan konseling

Tabel 4.

Rangkuman Perhitungan Data Motivasi Siswa Melanjutkan Konseling

\begin{tabular}{|l|l|}
\hline Mean & 120,56 \\
\hline Median & 122,00 \\
\hline Mode & 122 \\
\hline Standar deviasi & 22,310 \\
\hline Skor minimal & 46 \\
\hline Skor maksimal & 166 \\
\hline Total skor & 7957 \\
\hline
\end{tabular}

Selanjutnya untuk mengetahui tingkat motivasi siswa melanjutkan konseling, maka data penelitian yang telah dianalisis dibandingkan dengan kategori yang telah ditentukan sebagai berikut.

Tabel 5.

Kategori Pencapaian Skor Motivasi Melanjutkan Konseling

\begin{tabular}{|c|c|}
\hline Klasifikasi & Kategori \\
\hline 143 & Sangat tinggi \\
\hline $116-142$ & Tinggi \\
\hline $89-115$ & Sedang \\
\hline $62-88$ & Rendah \\
\hline$\leq 61$ & Sangat rendah \\
\hline
\end{tabular}


Dari hasil perhitungan dan setelah dibangdingkan dengan kategori yang telah ditetapkan rata-rata pencapaian skor berada pada kategori tinggi, dengan demikian disimpulkan bahwa motivasi siswa untuk melanjutkan konseling di SMP Negeri 13 Padang berada pada kategori tinggi.

Table 6.

Rekapitulasi Perolehan Skor Motivasi Siswa Melanjutkan Konseling untuk Setiap Indikator

\begin{tabular}{|c|l|c|c|c|c|c|}
\hline No & $\begin{array}{l}\text { Motivasi Siswa } \\
\text { Melanjutkan Konseling }\end{array}$ & SI & ST & SR & Rata-rata & Ket \\
\hline 1 & $\begin{array}{l}\text { Keinginan Melanjutkan } \\
\text { konseling }\end{array}$ & 65 & 59 & 16 & 43,41 & $\mathrm{~T}$ \\
\hline 2 & $\begin{array}{l}\text { Tingkah laku siswa } \\
\text { alam konseling }\end{array}$ & 45 & 43 & 11 & 32,43 & $\mathrm{~T}$ \\
\hline 3 & $\begin{array}{l}\text { Harapan terhadap } \\
\text { konseling }\end{array}$ & 60 & 59 & 19 & 44,71 & $\mathrm{~T}$ \\
\hline
\end{tabular}

Berdasarkan table rekapitulasi data motivasi siswa melanjutkan konseling, secara rata-rata motivasi siswa untuk melanjutkan konseling tinggi.

\section{PEMBAHASAN}

Pembahasan hasil penelitian ini berdasarkan rumusan dan tujuan penelitian. Hasil penelitian menunjukan kemampuan guru BK membina hubungan konseling berada pada kategori tinggi. Setelah melakukan perhitungan dan analisis terhadap data kemampuan guru BK membina hubungan konseling, diperoleh skor rata-rata kemampuan guru BK membina hubungan konseling 150. Kemampuan guru BK membina hubungan konseling sangat dipengaruhi oleh kemampuan guru BK dalam menjalin kepedulian dan kehangatan, empati, dan kesegeraan guru BK dalam menerima siswa yang ingin konseling.

Kemampuan guru BK membina hubungan konseling terkait erat dengan komitmen guru BK untuk sepenuh hati menerima dan mensukseskan proses konseling yang dilaksanakan. Munro (1983: 11) menjelaskan bahwa guru BK atau konselor dalam melaksanakan konseling harus bertanggung jawab atas tingkah lakunya sendiri dan memperhatikan kebahagiaanya kliennya. Dengan sikap dan kemampuan guru BK dalam membina tanggung jawabnya melaksanakan konseling, akan menyebabkan konseli merasa nyaman dan memiliki persepsi positif terhadap upaya guru BK membantu mengatasi masalah siswa.

Kemampuan guru BK membina hubungan konseling memperoleh skor yang cukup baik, dengan kategori tinggi. secara umum responden penelitian menilai bahwa guru BK mampu mengembangkan hubungan konseling yang membuat siswa merasa dihargai dan diperhatikan oleh guru BK atau konselor. Keberhasilan penyelenggaraan proses konseling di sekolah tidak terlepas dari kemampuan konselor atau guru BK dalam membina hubungan yang baik dengan konseli. Membina hubungan dalam proses konseling merupakan suatu kemampuan yang harus dikembangkan oleh konselor. Kemampuan membina hubungan akan berpengaruh terhadap pandangan siswa terhadap konselor, sikap siswa untuk percaya terhadap konselor, dan keterbukaan dalam mengungkapkan masalah yang sedang dialami kepada konselor (Munro, 1983:35).

Motivasi Siswa Melanjutkan Konseling dalam penelitian ini merupakan variabel terikat yang dipengaruhi oleh kemampuan guru BK membina hubungan konseling. Berdasarkan analisis terhadap data penelitian, motivasi siswa melanjutkan konseling berada pada kategori tinggi. perolehan skor rata-rata sebesar 37,29 dengan persentase 63,63\%. Motivasi siswa mengikuti konseling terkait dengan indikator keinginan siswa untuk melanjutkan konseling. Hasil penelitian tersebut menunjukkan bahwa setelah siswa mengikuti konseling, siswa memiliki keinginan untuk melanjutkan kembali proses konseling ketika mengalami masalah atau ketika masalahnya belum terentaskan. Keinginan melanjutkan konseling dari siswa secara sukarela dan penuh kesadaran 
pada dasarnya adalah hasil dari kemampuan guru BK untuk menciptakan kondisi yang nyaman dan penuh hubungan membantu kepada siwa yang mengikuti konseling. Prayitno dan Erman Amti (2004: 116) menjelaskan bahwa kesukarelaan adalah sikap yang diharapkan dalam proses konseling, kesukarelaan dari konseli berbentuk ketdakragu-raguan dalam mengungkapkan masalah. Pendapat tersebut menjelaskan bahwa, kesukarelaan konseli melanjutkan konseling karena konseli telah merasa memiliki kesukarelaan dan memandang konselor sebagai pihak yang bisa untuk mengatasi masalah yang dihadapinya.

Motivasi siswa melanjutkan konseling terkait juga dengan harapan-haparan siswa terhadap konseling. Harapan-harapan siswa terhadap konseling merupakan faktor yang mendasari seseorang untuk mengikuti konseling. Peran atau fuungsi pokok adanya harapan terhadap aktifitas seseorang seperti yang diungkapkan oleh Ahmadi (2007:178) yaitu faktor kebutuhan (need) individu terhadap sesuatu dapat membangkitkan motivasinya untuk melakukan suatu aktifitas. Kebutuhan-kebutuhan yang dimiliki oleh siswa terhadap konseling perorangan berpengaruh terhadap bagaimana perasaan/ keinginan, dorongan dan harapan yang dimilikinya terhadap konseling perorangan.

Harapan-harapan yang dimiliki oleh siswa terhadap pelaksanaan konseling perorangan berkaitan dengan pengembangan diri dan pengentasan permasalahan tentang berbagai bidang kehidupan. Prayitno (1997:50) menyebutkan bahwa pelaksanaan Bimbingan dan Konseling di sekolah menengah secara umum dan khususnya konseling perorangan meliputi: (1) bidang bimbingan pribadi, (2) bidang bimbingan sosial, (3) bidang bimbingan belajar dan (4) bidang bimbingan karir. Harapan-harapan siswa yang positif terhadap diperolehnya pengetahuan baru berdasarkan bidang bimbingan yang ada, mengindikasikan tingginya motivasi siswa untuk mengikuti konseling perorangan secara langsung dengan Konselor.

\section{SIMPULAN, IMPLIKASI DAN SARAN Kesimpulan}

Berdasarkan temuan penelitian, dan juga telah melakukan pembahasan terhadap temuan-temuan penelitian, maka dapat dirumuskan kesimpulan penelitian yang sesuai dengan rumusan masalah dan tujuan penelitian, yaitu sebagai berikut:

1. Kemampuan guru BK SMP N 13 Padang dalam membina hubungan konseling berada pada kategori tinggi. Pada ketiga indikator kemampuan membina hubungan konseling, yaitu: a) kemampuan membina kepedulian dan kehangatan, berada pada kategori tinggi. Siswa merasa guru BK baik dalam membina kehangatan dan kepedulian. Hal ini terlihat dari perhatian guru BK yang besar terhadap siswa, selain itu guru BK juga mau menerima siswa dengan hangat dan memberika tanggapan yang baik terhadap apa yang dikatakan siswa. b) Kemampuan guru BK dalam membina empati berada pada kategori tinggi. Artinya guru BK sudah cukup baik dalam membina empati dengan siswa. Siswa merasa guru BK dapat merasakan dan memahami apa yang sedang siswa alami. Guru BK juga mengerti bagaimanapun kondisi siswa dan tidak pernah menyalahkan atau menyudutkan siswa. c) Kemampuan guru BK dalam membina kesegeraan, rata-rata berada pada kategori tinggi. Hal ini menunjukkan bahwa guru BK siap dan tepat dalam membantu siswa ketika membutuhkan bantuan. Siswa merasa guru BK bisa menjadi tempatnya mengadu atau sekedar minta pendapat.

2. Motivasi siswa SMP N 13 Padang untuk melanjutkan konseling berada pada kategori tinggi. Seluruh indikator tentang motivasi siswa melanjutkan konseling yang diteliti, yaitu: a) Keinginan siswa melanjutkan konseling berada pada kategori tinggi. Hal ini terlihat dari sikap siswa yang senang konseling dengan guru BK karena siswa punya keyakinan untuk dapat menyelesaikan masalah dengan bantuan guru BK. b) Tingkah laku siswa dalam konseling rata-rata berada pada kategori tinggi. Artinya tingkah laku siswa baik dan positif ketika konseling dengan guru BK. Hal itu terlihat dari sikap siswa yang dapat terbuka dan tanpa ragu-ragu untuk menceritakan masalah yang dialami kepada guru BK. Siswa juga dengan sukarela mendatangi guru BK untuk konseling, tanpa perlu dipanggil atau dipaksakan. c) harapan siswa pada konseling secara rata-rata berada pada kategori tinggi. Hal ini terlihat dari harapan siswa yang besar 
untuk dapat mengatasi segala masalahnya dengan konseling dan siswa berharap banyak kepada guru BK untuk dapat membantunya.

Terdapat hubungan yang signifikan antara kemampuan guru membina hubungan konseling dengan motivasi siswa melanjutkan konseling. Hasil penelitian menunjukan bahwa, kemampuan guru membina hubungan konseling berada pada kategori tinggi, dan motivasi siswa untuk melanjutkan konseling juga berada pada kategori tinggi.

\section{Implikasi}

Beberapa implikasi yang perlu dilakukan oleh guru BK yakni sebagai berikut:

1. Menunjukkan sikap siap dan ramah ketika siswa datang menemui guru BK. Bahwa sedikit atau banyak siswa memerlukan layanan konseling perorangan terkait dengan kemampuan guru BK dalam membina hubungan dengan para siswanya. Oleh karena itu guru BK perlu menunjukkan sikap hangat ketika siswa datang menemuinya melayani dengan penuh kepedulian, kehangatan, empati dan kesegeraan. Sehingga memberikan kesan pada siswa bahwa guru BK benar-benar peduli dengan siswa.

2. Meningkatkan kemampuan membina hubungan konseling. Berdasarkan hasil penelitian, kemampuan guru BK membina hubungan konseling berada pada kategori tinggi, akan tetapi jika dilihat satu persatu masingmasing jawaban dari item pernyataan terdapat hasil pengolahan yang skornya rendah. Butir-butir pernyataan tersebut ketika siswa datang guru BK menanyakan kabar atau kesehatan siswa, guru BK dapat merasakan yang siswa alami, guru BK tidak menyalahkan siswa, guru BK dapat membuat suasana konseling nyaman.

\section{Saran}

Berdasarkan hasil penelitian, maka terdapat beberapa saran yang dapat dikemukakan kepada pihak-pihak terkait, yaitu sebagai berikut:

\section{Guru BK atau Konselor}

Guru BK disarankan dapat meningkatkan kemampuan membina hubungan konseling khususnya dalam membina kepedulian, kehangatan, empati dan kesegeraan dengan siswa. Apabila kemampuan itu belum dimiliki secara baik oleh guru BK disarankan guru BK untuk mengikuti berbagai macam pelatihanpelatihan, seminar dan lain sebagainya untuk meningkatkan kemampuan guru BK dalam membina hubungan konseling yang dapat menjadikan profesional. Serta dapat meningkatkan dan pengembangan kemampuan membina hubungan konseling secara efektif guna meningkatkan motivasi siswa melanjutkan konseling. Guru BK juga disarankan menyusun dan melaksanakan program pelayanan Bimbingan dan Konseling, khususnya tentang layanan layanan informasi dan layanan bimbingan dan kelompok mengenai materi yang berkaitan dengan konseling perorangan.

\section{Jurusan BK UNP}

Disarankan kepada Ketua Jurusan Bimbingan dan Konseling Fakultas Ilmu Pendidikan Universitas Negeri Padang untuk menyusun program-program pembelajaran yang memberikan pengetahuan, pembentukan, pengembangan dan pelatihan mengenai kemampuan membina hubungan konseling yang profesional kepada mahasiswa calon Konselor, melalui mata kuliah yang khusus membahas tentang kepribadian Konselor profesional.

Selain itu jurusan BK dapat melahirkan lulusan-lulusan mahasiswa BK yang memiliki keterampilan dalam melakukan konseling perorangan. Dan sebagai bahan masukan dalam membekali mahasiswa dengan kemampuan praktikum Bimbingan dan Konseling, khususnya melalui praktik-praktik konseling individual 
dan juga melatih komunikasi dan sikap guru BK menghadapi konseli yang memiliki perbedaan dan karakterisitik.

\section{Peneliti}

Dapat dijadikan sebagai dasar penelitian lanjutan dengan memperluas variabel dan subjek penelitian serta penelitian pengembangan tentang model peningkatan kemampuan guru BK membina hubungan konseling, dan model peningkatan motivasi siswa melanjutkan konseling.

\section{DAFTAR RUJUKAN}

Ahmadi, Abu. 1991. Bimbingan dan Konseling di Sekolah. Jakarta: PT. Rineka Cipta.

Brammer L.M \& E.L Shostrom. 1982. Therapeutic Psychology: Fundamentals of Counseling and Psychoterapy. New Jersey: Prentice-Hall.

Emzir, 2008. Metodologi Penelitian Pendidikan Kuantitatif \& Kualitatif, Jakarta: Pt Grafindo Persada.

Lesmana , Jeanette. Murad. 2008. Dasar-Dasar Konseling. Jakarta: UI-Press.

Munro, E.A dkk. 1983. Penyuluhan (Counseling): Suatu Pendekatan Berdasarkan Keterampilan. Terjemahan oleh Erman Amti (Ed). Jakarta: Ghalia Indonesia.

Nurihsan, Achmad Juantika. 2005. Strategi Layanan Bimbingan Dan konseling. Bandung: Refika Aditama.

Prayitno \& Erman Amti.2004. Dasar-Dasar Bimbingan dan Konseling.Jakarta: Rineka Cipta

Prayitno, 2009. Wawasan Profesional Konseling. Padang: UNP Press

Surya, M. 1988. Dasar-dasar Penyuluhan (Konseling). Jakarta: Proyek Pengembangan Lembaga Pendidikan Tenaga Kependidikan.

Yusuf, A. Muri. 2005. Metodologi Penelitian: Dasar-dasar Penyelidikan Ilmiah. Padang: UNP Press. 